\title{
Spatial and seasonal variations in phytoplankton community structure in alkaline-saline Lake Nakuru, Kenya
}

\author{
Oyoo Elijah Okoth, ${ }^{1 *}$ Muchiri Mucai, ${ }^{1}$ Wiliam A. Shivoga, ${ }^{2}$ Scott N. Miller, ${ }^{3}$ Joseph Rasowo ${ }^{4}$ \\ and Charles Chege Ngugi ${ }^{1}$ \\ ${ }^{1}$ Department of Fisheries and Aquatic Sciences, Moi University, PO Box 1125, Eldoret Kenya, ${ }^{2}$ Department of Environmental \\ Science, Egerton University, PO Box 536, Njoro, Kenya, ${ }^{3}$ Department of Renewable Resources, University of Wyoming, \\ Laramie, Wyoming, USA, and ${ }^{4}$ Department of Biological Sciences, Moi University, PO Box 1125, Eldoret, Kenya
}

\begin{abstract}
Spatial and seasonal variations of phytoplankton, expressed in terms of species composition, cell density, biovolumes and biomass, collected at 10 sampling sites in alkaline-saline Lake Nakuru, Kenya, were investigated monthly from March 2004 to February 2005, in relation to selected physical and chemical water quality parameters. A total of eight species, belonging to five genera and three classes, were recorded. The Cyanophyceae comprised the bulk of the phytoplankton, followed by Euglenophyceae, while Bacillariophyceae were the least abundant. Arthrospira fusiformis was the most dominant species, in terms of density, among the Cyanophyceae, while Euglena spp. and Navicula elkabs dominated the Euglenophyceae and Bacillariophyceae density, respectively. Seasonal variations in phytoplankton species composition, density and biomass were significant $(P<0.05)$ with minimum cell density and biomass occurring during the dry season, and being maximum following the end of the two rainy seasons from May to November 2004, suggesting the possible influence of various environmental factors on the lake. Sampling sites located close to the inlets of inflowing rivers exhibited significantly $(P<0.05)$ higher phytoplankton cell density and biomass than those by the inshore sites. Soluble reactive phosphorus, ammonia-nitrogen, conductivity and total alkalinity accounted for most of the variations in the cell densities of phytoplankton species.
\end{abstract}

\section{Key words}

community structure, Lake Nakuru, phytoplankton, species distribution.

\section{INTRODUCTION}

Most aquatic systems around the world, including rivers, lakes and reservoirs, have undergone changes because of human-induced disturbances from land-use activities centred on agriculture and industrial activities, and human settlements (Kuang et al. 2004). As one example, numerous factors have contributed over past years to degradation of water resources in the River Njoro watershed in Kenya (Shivoga et al. 2007). Not unexpectedly, the character of a lake is determined by the character and magnitude of the basin draining into it,

*Corresponding author. Email: elijaoyoo@yahoo.com

Accepted for publication 1 December 2008. mainly because the ecosystems of lentic waterbodies are closely linked to the physical, chemical and biological processes occurring within the entire watershed. The cumulative effects of the quality of the water draining from the catchments areas will ultimately influence the ecological integrity of any recipient waterbodies. Thus, in order to determine the influence of the water draining from the River Njoro catchment on the integrity of Lake Nakuru, a small, shallow, alkaline-saline, endorheic lake situated at the lowest point in the Njoro River watershed, studies of changes in the populations of aquatic organisms in Lake Nakuru, in relation to water quality parameters, are essential.

Phytoplankton, as primary producers, forms the vital energy source at the first trophic tier. As they also serve as 
food to many aquatic animals, they also have an important role in the material circulation in aquatic ecosystems by controlling the growth, reproductive capacity and population characteristics of aquatic biota. Furthermore, their standing crops exhibit variations that depend on several factors, including: (i) the supply of major nutrients (mainly phosphorus and nitrogen); (ii) light availability; (iii) grazing by zooplankton; (iv) water mixing regimes; and (v) basin morphometry (Reynolds et al. 2001; Gurung et al. 2006). Evaluation of phytoplankton community structure is essential, therefore, to evaluation of the water environment. To this end, recent studies in Kenya on phytoplankton community structure, dynamics and productivity, have been conducted in a variety of freshwater lakes, enriching our knowledge and understanding of the phytoplankton ecology and community structures in such lakes. Similar studies in the saline-alkaline lakes of Kenya, however, are rare and sporadic. As an example, limnological surveys highlighting phytoplankton dynamics in Lake Nakuru date back to the 1929 expeditions. These initial efforts were followed by several elaborate, but fewer, studies in the 1970s and 1980s (Milbrink 1975; Vareschi 1978; Vareschi 1982; Mwatha 1983; Vareschi \& Jacobs 1985). Considering that the lake supports a large biotic assemblage of avian fauna dependent on phytoplankton populations residing in it, current management challenges for this lake will ultimately depend on the availability of information on its phytoplankton community structure. This is evidence from earlier research by Sileo et al. (1979), which established that phytotoxic algal blooms resulting from changed water quality have been associated with episodic mortalities of lesser flamingos (Phoeniconaias minor) in the lakes. Moreover, no recent studies can be documented in this lake concerning the phytoplankton community structure, which necessitates constant monitoring of ecological conditions in the lake as a means of providing a current database of its environmental conditions. Accordingly, the goal of this study was to investigate the spatial and seasonal variations in phytoplankton species composition, numerical cell density and biomass, in relation to changes in water quality parameters. The research objectives, included: (i) determining the spatial variation in phytoplankton species composition, cell density, cell biovolume and biomass of Lake Nakuru; (ii) determining the seasonal variation in phytoplankton species composition, cell density, cell biovolume and biomass of Lake Nakuru; and (iii) relating changes in phytoplankton cell density to changes in the physicochemical water quality parameters. Such information is necessary for managing Lake Nakuru and other similar waterbodies elsewhere in the world.

\section{METHODS \\ Study area}

The Lake Nakuru study area, including the sampling sites, is illustrated in Fig. 1. The lake $\left(36^{\circ} 05^{\prime} \mathrm{E}, 0^{\circ} 22^{\prime} \mathrm{S}\right)$ is a small, shallow, alkaline-saline endorheic lake situated within Lake Nakuru National Park, $\approx 160 \mathrm{~km}$ north-west of the Kenyan capital city of Nairobi, at an altitude of $1759 \mathrm{~m}$ asl. It has a surface area of $40-60 \mathrm{~km}^{2}$, average depth of $1 \mathrm{~m}$, and catchment area of $\approx 1800 \mathrm{~km}^{2}$ (SUMAWA 2004). The air temperature ranges between $8-28^{\circ} \mathrm{C}$. A bimodal rainfall pattern is normally experienced in the region. The socalled long rains often fall between the months of March to May, and the short rains fall from September to October. December to February are typically dry months. Monthly variations in the quantity of precipitation recorded at the Lake Nakuru Meteorological station during the study period is summarized in Fig. 2. The lake is known for its spectacular bird fauna, particularly the lesser flamingo (Phoeniconaias minor). Other aquatic animal communities within Lake Nakuru include the greater flamingo (Phonocopterus ruber), pelican (Pelicanus onocrotalus), a copepod (Lovenula africana) and midge larva (Leptochironomous deribae). A cichlid fish (Oreochromis alcalicus grahami) also was introduced into the lake. The main human activities within the lake catchment include crop farming (mainly maize and wheat), dairy farming and horticulture.

\section{METHODS}

Samples were taken at 10 georeferenced sampling sites at monthly intervals from March 2004 to February 2005 for the determination of phytoplankton species composition, cell density, biovolumes and biomass, and for selected physicochemical parameters. The georeferenced sampling sites were established during a previous Kenya Wildlife Service monitoring programme, and also were the sites used in earlier expeditions by Talling and Talling (1965), Milbrink (1975) and Vareschi $(1978,1982)$. They included both inshore sites, which were closer to discharge point of the inflowing rivers, and offshore areas, which were further away from the discharge point of the river inlets (Fig. 1).

Triplicate samples of all parameters were collected at the surface $(0 \mathrm{~m})$ and bottom $(1 \mathrm{~m})$ depths in Lake Nakuru. Dissolved oxygen (DO), temperature, conductivity and pH were measured in situ at each sampling sites, using a calibrated JENWAY 3405 electrochemical analyser (Barloword Scientific Ltd, Essex, UK), with independent probes for each variable. The equipment was calibrated at the Lake Nakuru Water Quality Laboratory before 
Fig. 1. Map of Lake Nakuru, indicating sampling sites and location of lake within Kenya.

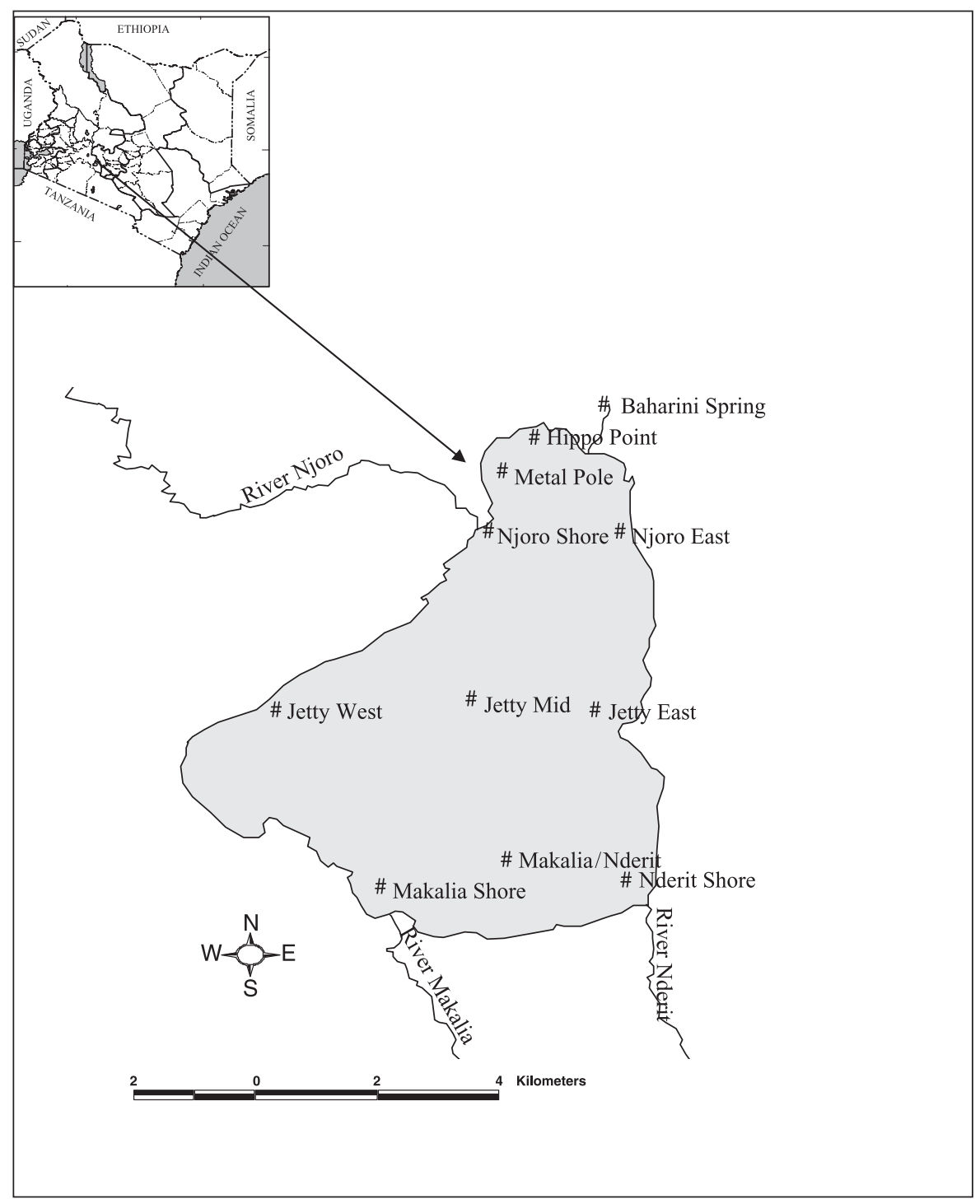

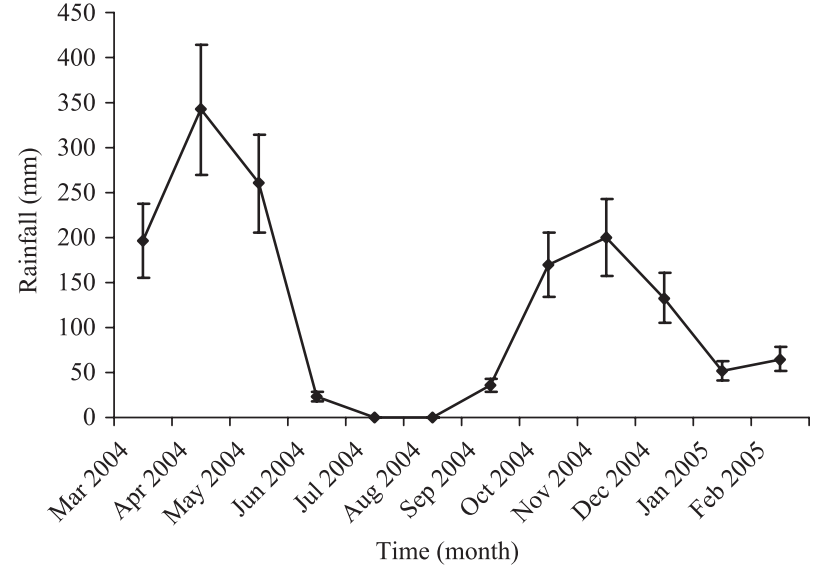

Fig. 2. Mean precipitation ( \pm standard error of the mean) recorded during study period (Source: Meteorological Station, Nakuru District). sampling, using de-ionized water, and also before any samples were taken. Water samples were collected for nutrient determination with a calibrated 3-L van Dorn sampler. Portions of the water samples were used to determine: (i) nitrite nitrogen $\left(\mathrm{NO}_{2}-\mathrm{N}\right)$ by the sulphanilamide diazotizing method; (ii) nitrate nitrogen $\left(\mathrm{NO}_{3}-\mathrm{N}\right)$ by the diphenylamine sulphonic acid chromogene method; (iii) ammonia nitrogen $\left(\mathrm{NH}_{3}-\mathrm{N}\right)$ by the indophenol blue method (Boyd 1990); (iv) soluble reactive phosphorus (SRP) by the standard ascorbic acid method, after filtration of the sample through a $45-\mu \mathrm{m}$ pore membrane; and (v) total alkalinity (TA) by the acidimetric method, using sulphuric acid as the titrant. The analyses were conducted at the Lake Nakuru Water Quality Laboratory, following the standard analytical procedures detailed in APHA (1998), except for $\mathrm{NH}_{3}-\mathrm{N}$. 
Phytoplankton were collected by plankton net $(10-\mathrm{mm}$ mesh), and fixed with Lugol's solution. One litre quantitative samples were fixed in iodine, sedimented for $24 \mathrm{~h}$, and concentrated to $50 \mathrm{~mL}$. Numerical phytoplankton identification was carried out with a compound microscope (OlumpusBHS, Japan; $400 \times$ magnification), using several keys and illustrations. The Cyanophyceae were identified with the techniques of Huber-Pestalozi (1938), Prescott (1954) and Vollenweider (1969), while the identification of Bacillariophyceae was based on the techniques of Hustedt (1942), Bourrelly (1972) and Krammer and Lange-Bertlot (1986-1991). Techniques of Ettl (1983), Komärek and Fott 1983) and Lenzenweger (1996) were used to analyse the Chlorophyceae. The nomenclatural authorities are identified in Table 2.

Phytoplankton cell density (individuals. $\mathrm{mL}^{-1}$ ) was estimated by counting all individuals, including single cells, colonies and filaments on a cell-by-cell basis. A Sedgwick-Rafter cell was used to count the phytoplankton. The biovolumes of the phytoplankton species were calculated on the basis of the formula for solid geometric shapes that most closely matched the cell shape. Mean cell volume was based on calculations of the volume of 30 individual cells. Taxa were then assigned to one of the above-noted three size classes. The total biovolume for each taxon was calculated from cell numbers, and used to identify the dominant taxa in each size class. Estimates of phytoplankton biomass in the water column were based on chlorophyll- $a$ concentrations. The vertical profiles of chlorophyll- $a$ pigment were integrated over the water column to a depth of $1 \mathrm{~m}$. Vertically integrated chlorophyll was averaged by standard sampling sites. After being extracted for $24 \mathrm{~h}$ in $10 \mathrm{~mL}$ of $90 \%$ acetone, the chlorophyll$a$ samples were filtered through Whatman GF/C glass fibre filters (Whatman International Limited, Maidstone, Kent, UK). The chlorophyll- $a$ concentration in the extract was measured with a spectrophotometer at a wavelength of $665 \mathrm{~nm}$ and $652 \mathrm{~nm}$, and corrected for pheophytin according to Lorenzen (1969).

\section{Statistical analyses}

Mean differences in the physicochemical parameters among sites, as well as monthly variations, were analysed with a one-way ANOvA test, while differences in spatial and temporal variability were analysed with a two-way ANovA test. Duncan's multiples range test was used for post-hoc discrimination between the means that were different from each other (Michael \& Douglas 2004). Mean differences in phytoplankton cell density and biovolume among sites, and among seasons, were analysed by non-parametric Kruskal-Wallis ANOvA (Kruskal \& Wallis 1952). To establish phytoplankton distribution and community structure, the percentages of species contribution were subjected to exploratory cluster analysis, and similar stations were classified in terms of species composition and cell density structure. The dichotomous classification technique expressed the occurrence of organisms in an ordered table, constructed from site-taxa matrix. The outputs are viewed as dendrograms that illustrate sampling sites exhibiting similar species composition. For ease of comparison, the scale was reduced to percentage by dlink/dmax ${ }^{\star} 100$. The independent interrelationships between physicochemical parameters and phytoplankton cell density were examined, using Spearman rank correlation. The significance of the correlation coefficient was computed with the Student-Newman-Keules (SNK) test. All analyses were carried out using the STATISTICA for Windows software package (StatSoft 2001).

\section{RESULTS \\ Physicochemical parameters}

The values of physicochemical parameters recorded among the sampling sites during this study are summarized in Table 1 . With the exception of spatial variation in surface water temperatures, all other physicochemical parameters demonstrated significant $(P<0.05)$ spatial variations. Sampling sites located near the incoming rivers (except River Njoro shore) exhibited significantly higher DO concentrations than the inshore sites $(P<0.05)$. All sampled sites exhibited high DO concentrations ( $>100 \%$ saturation; Table 1 ) throughout the study period. Spatial variations in $\mathrm{pH}$ also were significant $(P<0.05)$. The $\mathrm{pH}$ measured at the offshore sites was less than those measured at the inshore sites. The electrical conductivity measured at the southern inshore sites was higher than for the other sites, although no discernable spatial variations patterns in conductivity were obtained. Distinct patterns of spatial variability, however, were observed for TA. Metal Pole, Makalia-Nderit, Makalia Shore Nderit Shore and Njoro shore, for example, all of which are located next to incoming rivers, exhibited higher TA values than for the other sampling sites $(P<0.05)$. Although higher $\mathrm{NO}_{2}-\mathrm{N}$ concentrations were recorded at the Jetty Mid and Makalia-Nderit sites, no distinct variation pattern was observed in regard to the sites located along the incoming rivers. The $\mathrm{NH}_{3}-\mathrm{N}$ and SRP concentrations were higher along all the inflowing river inlets. Distinct seasonal variations were discerned for all physicochemical parameters, except $\mathrm{NO}_{2}-\mathrm{N}$ (Fig. 3). The long, rainy seasons in May and June resulted in lower water temperatures, DO concentrations, conductivity, TA 


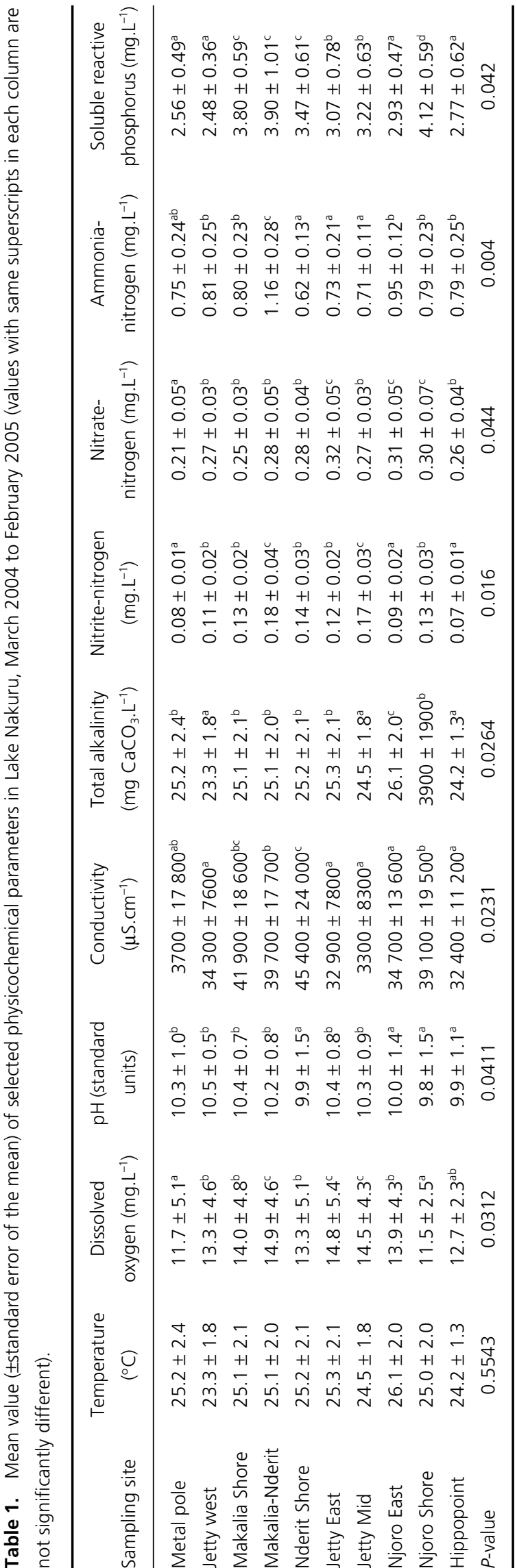

and $\mathrm{pH}$, but resulted in increased $\mathrm{NO}_{3}-\mathrm{N}, \mathrm{NH}_{3}-\mathrm{N}$ and SRP concentrations, compared to the dry season. During the rainy seasons, the sampling sites closer to the inflowing river inlets had significantly $(P<0.05)$ higher nutrients loads and lower DO concentrations than the inshore sites.

\section{Photoplankton species composition}

A total of eight phytoplankton species, belonging to five genera and three classes, were recorded during the study period. The Cyanophyceae were the most diverse, with six species, followed by a single species each of Euglenophyceae and Bacillariophyceae. Of these eight species, six were present during the dry seasons, and five during the rainy seasons (Table 2). Only A. fusiformis (formerly Spirulina platensis), Microcystis aureginosa and Euglena spp. were present at all 10 sampling sites in both the dry and the rainy seasons.

\section{Cell density and biovolume}

The phytoplankton cell density was dominated by Cyanophyceae, which accounted for $\approx 95 \%$ of the cells in the samples, followed by Euglenophyceae (4\%). Bacillariophyceae was the least abundant, accounting for only $1 \%$ of the cell density. Arthrospira fusiformis dominated the phytoplankton cell density during all sampling periods. The seasonal variations in the four most dominant individual phytoplankton cell densities from March 2004 to February 2005 are summarized in Fig. 4. The peak cell density of A. fusiformis, Spirulina major, Spirulina subsulsa and Euglena spp. occurred after long rainy periods. The populations of Anabaena circinalis, $M$. aeruginosa and Microcystis flos-aquae, however, declined during the rainy seasons. Cluster analysis revealed that the phytoplankton community structures among the sampled sites were similar during the dry seasons, except at the Hippopoint and Makalia-Nderit sites. In the rainy season, however, there was large variability in species structure among the sampling sites. The inshore sites clustered together, while the offshore stations were separated into several twin clusters (Fig. 5). Assessment of the spatial distribution indicated a higher cell density of all phytoplankton species for the surface samples than for the bottom samples, except for $N$. elkabs. Euglena spp. did not exhibit a preference for either the surface or the bottom layers. The peak monthly biovolumes coincided with the peak cell density during the rainy seasons. The monthly peak in variations for most sampling sites corresponded to rainy periods from April to June, and the other in August 2004. Spatial variations in cell biovolume also were significant $(P<0.05)$, while the inshore sampling sites had higher cell biovolumes than the other locations. 

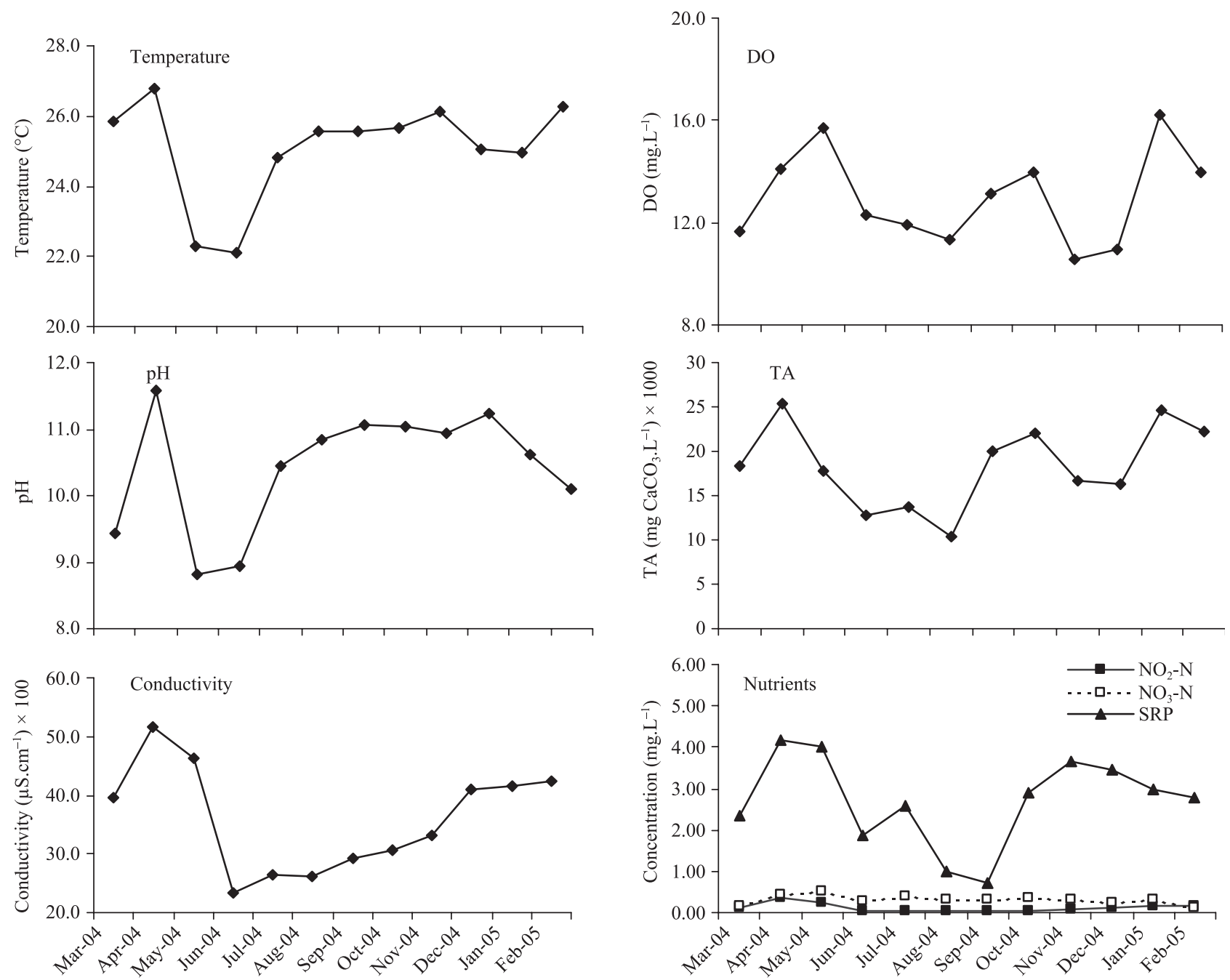

Fig. 3. Seasonal variations in selected physicochemical parameters for Lake Nakuru.

\section{Phytoplankton biomass}

Spatial and seasonal variations in the overall phytoplankton biomass are summarized in Fig. 6. The seasons variations in phytoplankton biomass was significant $(P<0.05)$, with two peaks observed, one being during May to June 2004, and the other in October 2004. Microcystis aeruginosa and Microcystis flos-aquae exhibited peak biomass values during the dry season of July to August. In all cases, the inshore sampling sites had significantly $(P<0.05)$ higher phytoplankton biomass than the other locations. The phytoplankton biomass was significantly $(P<0.05)$ higher at the water surface. At the bottom of the lake, the monthly phytoplankton cell density variations were not significant $(P>0.05)$.

\section{Interrelationships between phytoplankton cell density and water quality variables}

Based on Spearman rank order correlations, several significant relationships were observed between phytoplankton cell density and water quality variables (Table 3 ). Temperature, $\mathrm{DO}$ and $\mathrm{NO}_{2}-\mathrm{N}$ did not exhibit any significant correlations with all phytoplankton species $(P>0.05)$. The $\mathrm{pH}$ values, however, exhibited significant positive and negative correlation with $A$. fusiformis and $A$. circinalis, respectively $(P<0.05)$. The electrical conductivity was positively correlated to $M$. aeruginos $a$, and negatively correlated to A. fusiformis and S. subsulsa. The TA, $\mathrm{NH}_{3}-\mathrm{N}$ and SRP concentrations exhibited some degree of species-specific positive or negative correlation with all phytoplankton species. The $\mathrm{NO}_{3}-\mathrm{N}$ concentration exhibited a significant positive correlation only to $M$. aeruginosa $(P<0.05)$. Thus $\mathrm{SRP}, \mathrm{NH}_{3}-\mathrm{N}$, electrical conductivity and TA values exerted considerable influence on the phytoplankton community structure in Lake Nakuru.

\section{DISCUSSION}

The physicochemical environment of Lake Nakuru displayed considerable spatial and seasonal variation in 
Table 2. Phytoplankton species recorded during dry and rainy seasons in Lake Nakuru $((+)=$ present; $(-)=$ absent $)$

\begin{tabular}{|c|c|c|c|c|}
\hline Class & Genus & Species & $\begin{array}{l}\text { Dry } \\
\text { season }\end{array}$ & $\begin{array}{l}\text { Rainy } \\
\text { season }\end{array}$ \\
\hline \multirow[t]{6}{*}{ Cyanophyceae } & Spirulina & $\begin{array}{l}\text { Arthrospira } \\
\text { fusiformis } \\
\text { G.S. West }\end{array}$ & + & + \\
\hline & & S. major Clark & - & + \\
\hline & & $\begin{array}{l}\text { S. subsulsa } \\
\text { (Wittr.) Kirchn }\end{array}$ & - & + \\
\hline & Microcystis & $\begin{array}{l}\text { M. aureginosa } \\
\text { (Kütz.) Kürtz }\end{array}$ & + & + \\
\hline & & $\begin{array}{l}\text { M. flos-aquae } \\
\text { (Wittr.) Kirchn }\end{array}$ & + & - \\
\hline & Anabaena & $\begin{array}{l}\text { A. circinalis Rabh. } \\
\text { Ex Born. \& Fl. }\end{array}$ & + & - \\
\hline Euglenophyceae & Euglena & E. spp. & + & + \\
\hline Bacillariophyceae & Navicula & $\begin{array}{l}\text { N. elkabs } \\
\text { (Clark) Nyg. }\end{array}$ & + & - \\
\hline
\end{tabular}

relation to its prevailing environmental conditions. Some physicochemical parameters examined in this study were considerably outside the ranges reported for other similar alkaline-saline waterbodies (Ndetei \& Muhandiki 2005), as well as the water quality conditions in the lake measured in earlier studies (Talling \& Talling 1965; Vareschi 1978), indicating that the Lake Nakuru ecosystem has undergone fundamental shifts over time. These extreme variations in Lake Nakuru physicochemical parameters give this lake the distinction of displaying an extreme physical and chemical environment, which seem to interact in determining the nature and structure of the autotrophic assemblages of organisms in this aquatic system.

Although there was optimal temperature, DO concentration and nutrient availability in Lake Nakuru, offering good conditions for high algal diversity, only three algal classes (eight species) were observed in the samples collected during the 1-year sampling period, indicating that the lake was poor in species richness, and suggesting that its extreme water quality fundamentally shapes the ecological functioning of the lake. With the exception of
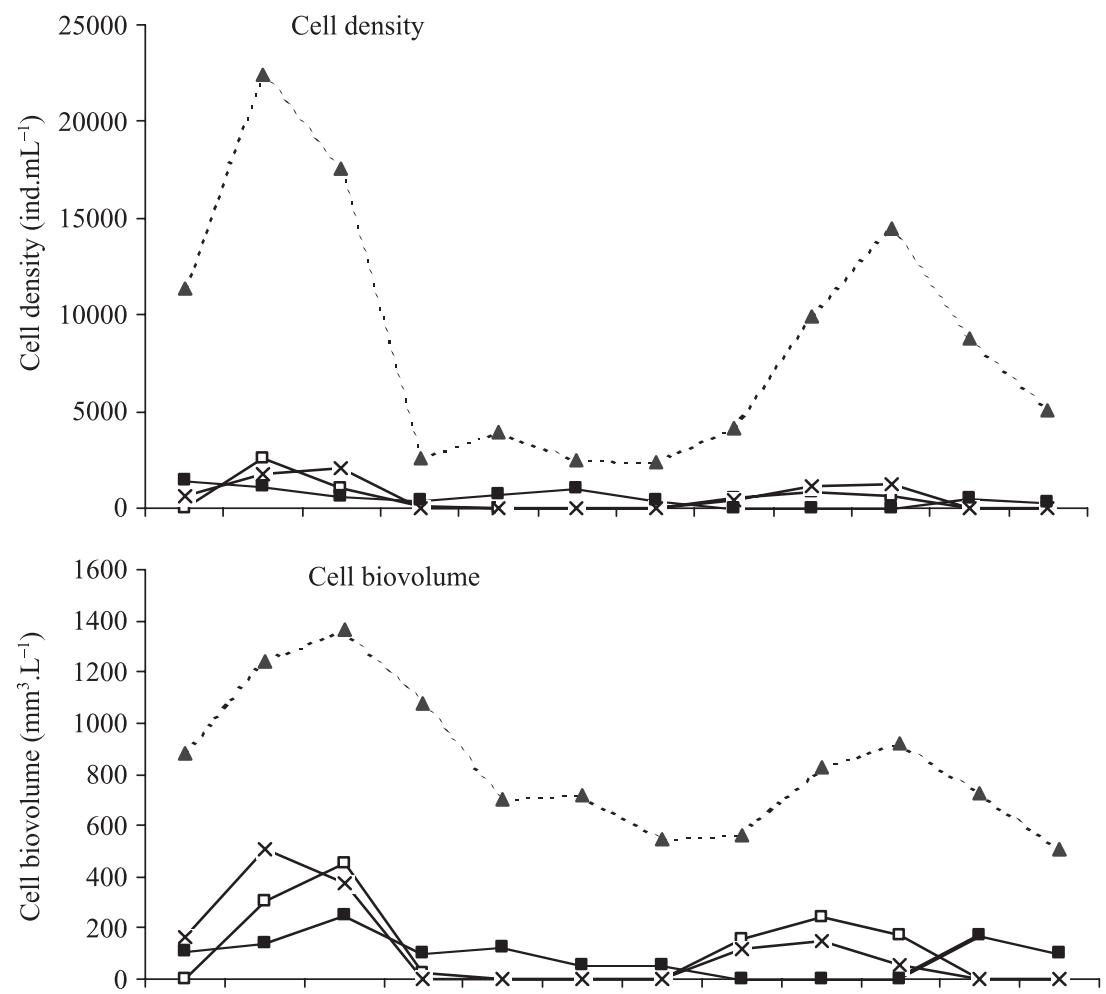

Fig. 4. Seasonal variations in cell density and biovolume of four most abundant phytoplankton species in Lake Nakuru, March 2004 to February 2005.

Time (months)

...... A. fusiformis $\longrightarrow-$ S. major $-\mathrm{x}-\mathrm{S}$. subsulsa $\longrightarrow$ Anabaena circninalis 

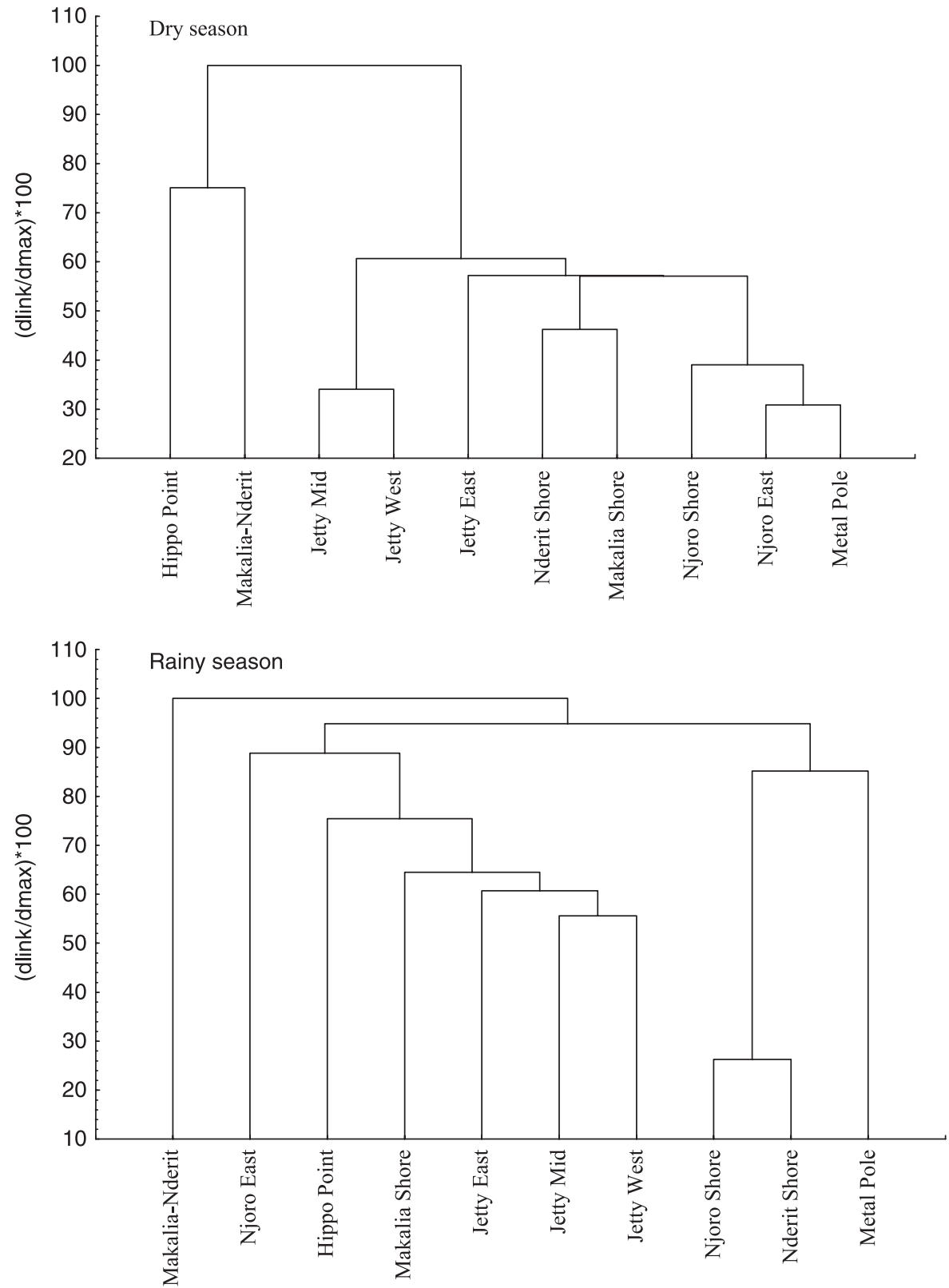

Fig. 5. Dendrogram illustrating phytoplankton classifications from different sampling sites, based on numerical cell density (scaling to dlink/dmax*100) of phytoplankton species during dry and the rainy seasons. the four observed species of cyanophytes, there was only two other phytoplankton classes, which had a single species each, in the lake. The lake's taxa composition also indicates a low species number which, although exhibiting some degree of similarity to other saline-alkaline lakes, were also unique in retrospect. Higher taxa compositions, for example, have been observed in other saline-alkaline environments that experience less human activities in their catchment areas (e.g. Lakes Magadi, Sonachi, Bogoria, and Natron (Ndetei, unpubl. data, 2001). The observed low species number in Lake Nakuru, particularly for the more tolerant Cyanophyceae and Bacillariaphyceae taxa, could be attributed to changes in habitat quality resulting from water quality changes originating from catchment areas that have undergone more land conversion to agriculture. Cyanophyceae have particular preferences for polluted environments because they grow in competitive interactions, with their enhanced ability to utilize carbon (mainly in polluted environments) at high $\mathrm{pH}$ levels, giving them an advantage over other phytoplankton species (Atici \& Olcay 2006). This observation seems to suggest that the water draining into Lake Nakuru from the River Njoro catchment has some degree of pollution. This possibility could explain the decline of Microcystis flos-aquae, A. circinalis and N. elkabs from the phytoplankton populations during the rainy 
Fig. 6. Spatial and seasonal variations in phytoplankton biomass in Lake Nakuru, March 2004 to February 2005.
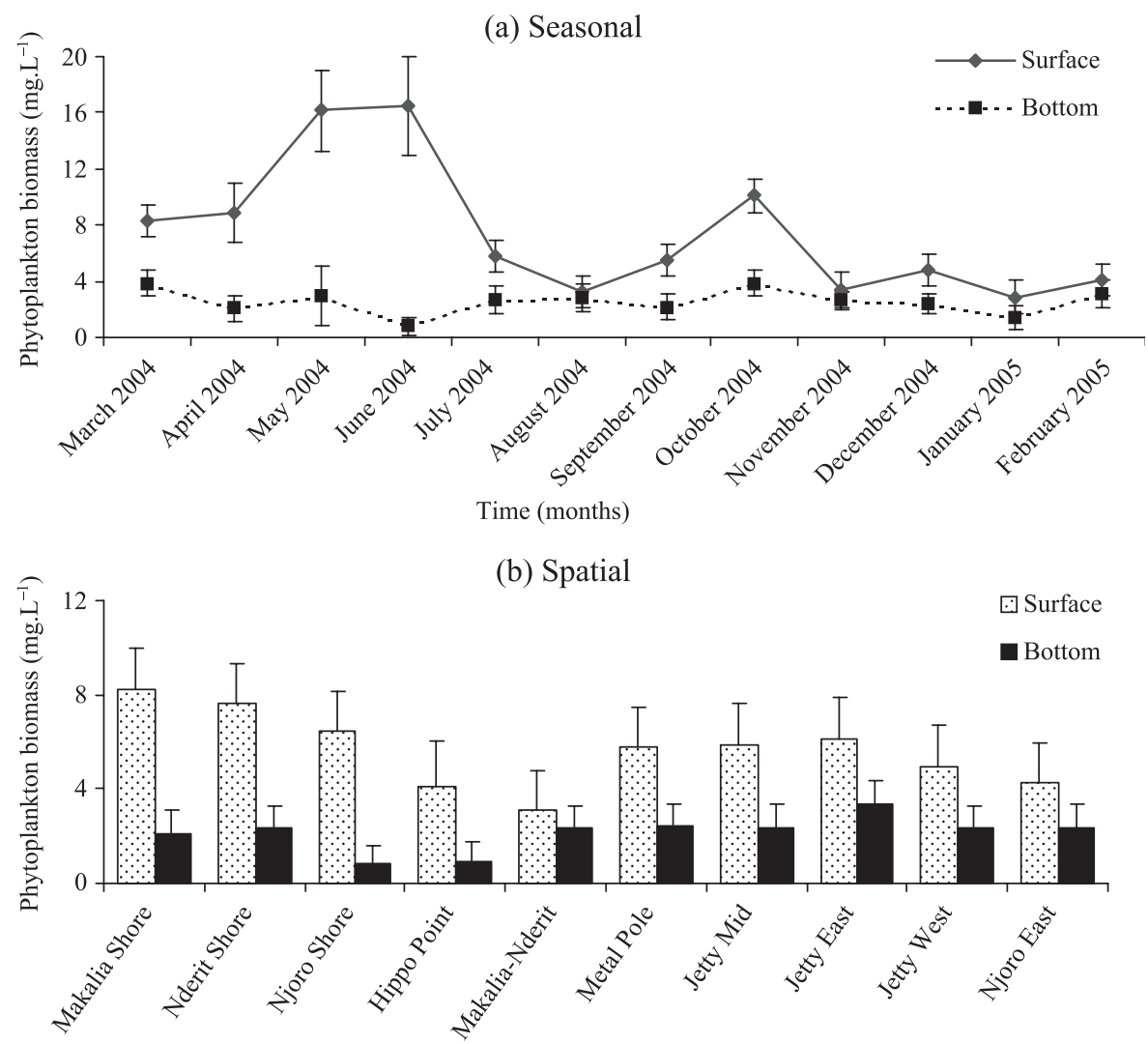

Site

Table 3. Spearman rank order correlation coefficients between physicochemical parameters and taxa and community structure attributes (** $=$ significant correlation at $\alpha=0.01 ; *$ significant correlation at $\alpha=0.05)$.

\begin{tabular}{|c|c|c|c|c|c|c|c|c|}
\hline Parameters & $\begin{array}{c}\text { A. } \\
\text { fusiformis }\end{array}$ & $\begin{array}{c}\text { S. } \\
\text { major }\end{array}$ & $\begin{array}{c}\text { S. } \\
\text { subsulsa }\end{array}$ & $\begin{array}{c}M . \\
\text { aureginosa }\end{array}$ & $\begin{array}{l}\text { M. flos- } \\
\text { aquae }\end{array}$ & $\begin{array}{c}\text { A. } \\
\text { circinalis }\end{array}$ & $\begin{array}{c}E . \\
\text { spp. }\end{array}$ & N. elkabs \\
\hline Temperature $\left({ }^{\circ} \mathrm{C}\right)$ & 0.13 & 0.03 & 0.02 & -0.03 & -0.03 & 0.07 & 0.08 & -0.01 \\
\hline Dissolved oxygen (mg. $\left.\mathrm{L}^{-1}\right)$ & -0.09 & -0.07 & -0.18 & -0.23 & 0.21 & 0.07 & -0.06 & $-0.07\left(\mathrm{mg} \cdot \mathrm{L}^{-1}\right)$ \\
\hline $\mathrm{pH}$ & $0.63^{*}$ & -0.15 & $-0.61 *$ & 0.15 & 0.14 & $-0.62^{*}$ & $0.69 *$ & 0.18 \\
\hline Conductivity $\left(\mu \mathrm{S} . \mathrm{cm}^{-1}\right)$ & $-0.68^{*}$ & 0.07 & $-0.67^{*}$ & $0.64 *$ & -0.14 & 0.02 & 0.03 & -0.11 \\
\hline Total alkalinity $\left(\mathrm{mg} \cdot \mathrm{L}^{-1}\right)$ & $-0.74^{* *}$ & $-0.69 *$ & $-0.72 *$ & $0.81 * *$ & $-0.74 * *$ & $-0.77 * *$ & 0.05 & $-0.66^{*}$ \\
\hline Nitrite-nitrogen $\left(\mathrm{NO}_{2}-\mathrm{N} ; \mathrm{mg} \cdot \mathrm{L}^{-1}\right)$ & -0.15 & 0.17 & -0.23 & -0.04 & -0.03 & 0.58 & 0.32 & $0.17\left(\mathrm{NO}_{2}-\mathrm{N} ; \mathrm{mg} \cdot \mathrm{L}^{-1}\right)$ \\
\hline Nitrate-nitrogen $\left(\mathrm{NH}_{3}-\mathrm{N} ; \mathrm{mg} \cdot \mathrm{L}^{-1}\right)$ & -0.09 & -0.13 & $0.81 * *$ & 0.08 & 0.09 & -0.16 & 0.12 & $0.17\left(\mathrm{NO}_{3}-\mathrm{N} ; \mathrm{mg} \cdot \mathrm{L}^{-1}\right)$ \\
\hline Ammonia-nitrogen $\left(\mathrm{NH}_{3}-\mathrm{N} ; \mathrm{mg} \cdot \mathrm{L}^{-1}\right)$ & $0.66^{*}$ & $0.63 *$ & $0.57^{*}$ & $0.71 *$ & $-0.72 * *$ & $-0.59 *$ & 0.23 & $0.17\left(\mathrm{NH}_{3}-\mathrm{N} ; \mathrm{mg} \cdot \mathrm{L}^{-1}\right)$ \\
\hline Soluble reactive phosphorus (SRP; mg. $\mathrm{L}^{-1}$ ) & $0.91 * *$ & $0.87 * *$ & $0.76^{* *}$ & $-0.66^{*}$ & $-0.58 *$ & $0.51 *$ & $0.69 *$ & $0.04\left(S R P ; m g . L^{-1}\right)$ \\
\hline
\end{tabular}

seasons. Relative to earlier studies (Talling \& Talling 1965; Mellack \& Kilham 1974; Milbrink 1975; Vareschi 1978; Vareschi 1982), there has been a progressive reduction of the number of phytoplankton taxa over time in this lake, suggesting the possible loss of diversity. Considering the urbanization of the town of Nakuru and its environs, together with continued destruction of River Njoro Watershed, occurred over the past 50 years (SUMAWA
2004), it is possible the population pressures in the catchment is leading to massive water quality changes that could alter the quality of the water draining into the lake, with subsequent impacts (alterations) on the species assemblage in this lake. This observation is supported by the fact that Milbrink (1975) identified over 20 species of blue green algae in lake samples over five decades ago. 
Contrary to the situation for other shallow, eutrophic lakes, wherein ideal conditions for the maximum growth of Chlorophyceae exist, cyanophytes dominated the cell density and biovolumes of phytoplankton populations in Lake Nakuru. Although it is generally agreed that Chlorophyceae are often more abundant than other classes of algae in shallow, tropical lakes (HowardWilliams \& Ganf 1981; Nkechinyere 2006), the dominance of few species of blue green algae, and the occurrence of few other algal taxa in lower cell density subject to changes in environmental conditions, could be an indicator of an extremely abiotic environment that exhibits characteristics beyond the tolerance thresholds of many taxonomic groups lacking a degree of specialization. This is supported by earlier studies on Lake Nakuru in 1929, which indicated that Chlorophyceae were the dominant algal taxa (Mellack \& Kilham 1974). Although the dominance of $A$. fusiformis in Lake Nakuru was documented from the 1960s (Talling \& Talling 1965), subsequent research often established a succession pattern that included dominance of Microcystis, Anabaena and Synechocystis (Milbrink 1975) at one time or the other. This condition clearly was not observed in this present study. The dominance of $A$. fusiformis in both the surface and the bottom water samples exhibited a positive correlation with $\mathrm{pH}, \mathrm{NH}_{3}-\mathrm{N}$ and $\mathrm{SRP}$, and a negative correlation with conductivity and TA, indicating that it can better tolerate high $\mathrm{pH}, \mathrm{NH}_{3}-\mathrm{N}$ and SRP concentrations. Vareschi (1982) previously reported that $A$. fusiformis also can tolerate a wide range of salinity ranges. As the lake salinity was not determined in this study, a potential role of salinity in shaping the population structure of $A$. fusiformis cannot be ruled out.

Seasonal variations in phytoplankton cell density and biovolume were significant. The peak cell densities and biovolumes corresponded to the onset of the rainy seasons. The cell densities of $A$. fusiformis, $S$. major, $S$. subsulsa and Euglena spp. increased during the rainy seasons, while the cell densities and biovolumes of $A$. circinalis, $M$. aeruginosa and $M$. flos-aquae were unexpectedly reduced by the inflow of water from the catchment, suggesting that the precipitation was not a significant reason for their cell density variations. Arthrospira fusiformis and Anabaena circinalis had higher cell density during the long rainy seasons of April to May. This observation, however, is contrary to those of Egborge (1979), and Atici and Olcay (2006), who reported increased phytoplankton cell density during the dry season, rather than the rainy season. Thus, current changes in the phytoplankton cells density appear to be directly related to the prevailing environmental conditions. Precipitation can play a critical role in determining limnological properties and plankton dynamics of lakes (Wetzel 1983; Kalff 2002) by washing a substantial quantity of allochthonous materials and nutrients from the catchment into the lake that can stimulate the growth and sustenance of phytoplankton populations, thereby also increasing phytoplankton cell density. In contrast, the increased water inflow into the lake from the rivers feeding it during the rainy season could decrease the lake water transparency, thereby reducing the availability of light in the water column to stimulate phytoplanktonic growth, especially for phytoplankton species residing some distance below the water surface.

Spatial variability is a structural character of an ecosystem. Spatial distributions allow for complex population interactions involving energy transfer, competition and niche apportionment (Brower et al. 1990). It is generally expected that less-disturbed sites exhibit a higher species diversity (Jones et al. 2002). Anthropogenic impacts from changes in land-use practices are known to affect phytoplankton diversity patterns in lakes receiving drainage from modified stream water quality from the catchments (Death 2000), often leading to decreased abundance of taxa, as well as shifts to a more unevenly distributed community containing only one or two numerically dominant taxa (Jones et al. 2002). The high level of dominance by a few taxa at sampling sites that experience water inflows compared to the more evenly distributed taxa in inshore sites, suggests that human activities already are shaping Lake Nakuru's phytoplankton communities. Kibichii et al. (2007) and Shivoga et al. (2007) reported a wide range of land-use activities in the upper reaches of the River Njoro. These human activities can ultimately affect spatial variations of species assemblage in Lake Nakuru. Site-specific differences in the phytoplankton cell density among the sampling sites were more pronounced between the offshore and inshore sites, making the lake appear heterogeneous. This apparent heterogeneity, however, could be attributed to the effects of water inflows from the Nakalia, Nderit, and Njoro Rivers, as well as the Baharini Spring. The lake is normally homogenous as diurnal winds mix its waters almost on a daily basis because of its small size and shallow depth. Mellack and Kilham (1974) reported a uniform distribution of species in the lake attesting to its homogeneity in relation to its biotic assemblages.

The phytoplankton biomass, as estimated by vertical profiles of chlorophyll- $a$ concentration in Lake Nakuru, was in excess of $1000 \mu \mathrm{g} . \mathrm{L}^{-1}$. This algal biomass, however, was contributed by only a very few phytoplankton species. In comparison to earlier studies by Vareschi (1982), the lake exhibits a higher biomass, but lower phytoplankton 
species diversity. Comparing the biomass value in Lake Nakuru to that of other saline-alkaline ecosystems around the world, Burgis \& Morris (1987) suggest that Lake Nakuru is characterized by hypertrophic conditions. The main reason for Lake Nakuru's high biomass is thought to be its shallow depth $(1 \mathrm{~m})$, which causes organic matter formed at the water surface, and in the middle water layer, not to sink to the lake bottom and become essentially immobilized, but rather to be recirculated intermittently. The matter is decomposed and then frequently stirred back into the lake's photic zone and quickly re-utilized by existing phytoplankton to produce more organic matter. The lake's phytoplankton biomass exhibited seasonal variations, with peak phytoplankton biomass occurring from May to June, 2004, which is just after the cessation of the long rains. The peak phytoplankton biomass during the rainy seasons corresponds to peak cell densities of dominant taxa.

Based on the correlation analysis results, four components (i.e. conductivity, TA, SRP, $\mathrm{NH}_{3}-\mathrm{N}$ ) affected the biomass of most phytoplankton species in Lake Nakuru. As the cell density (which is related to biomass) of $A$. fusiformis, S. major and $S$. subsalsa increased during the rainy seasons (corresponding to increased levels of SRP and $\mathrm{NH}_{3}-\mathrm{N}$ ), and the cell density of Anabaena and Microcystis declined in relation to increased nutrient levels, it could be concluded that the inflow of nutrients into Lake Nakuru from the River Njoro watershed plays a critical role in the lake's phytoplankton dynamics. Two peaks of phytoplankton biomass occurred during April and August for some species. Whereas the increased phytoplankton in relation to the rainy season could be explained by an increased nutrient input of nutrients, few abiotic factors explain the increased abundance of some phytoplankton in August 2004. Thus, it is worth noting that the phytoplankton biomass could have been influenced by factors other than the water quality parameters examined in this study. During the study period, the lake exhibited a high abundance of fish and flamingo, as reported by Ndetei and Muhandiki (2005), which feed directly on phytoplankton in the lake, thereby influencing the abundance and community structures of the latter. There are chances these organisms could control phytoplankton production by grazing. However, the rapid and abrupt periodicity of these specialized organisms over a short time span could also signal the presence of water quality perturbations.

The results of the present study indicate that there is a significant influence on the lake's biotic structure by water that originates from the catchment area and enters the lake through its influent river and impacts its phytoplankton population. The ecological functioning of Lake Nakuru appears to have been modified by the urbanization process of the nearby town of Nakuru because of the waterbody's close proximity to the town centre $(\approx 5 \mathrm{~km})$. Accordingly, lake management measures should focus on controlling pollutants from the town that can find their way into the waterbody. The dominance of Cyanophyceae, a constituent diet for the lake's flamingo population (Ndetei \& Muhandiki 2005), makes our knowledge of the determinants of phytoplankton community structure important for managing this lake and other similar lakes elsewhere that are experiencing related conditions. Although A. fusiformis has not been found to produce toxic secondary compounds, other cyanobacteria species (e.g. Microcystis; Anabaena) have produced cyanotoxins under conditions of changed water quality that, when consumed by the lake's flamingo populations, have caused their death. This underscores an urgent need for continuing monitoring of the lake's phytoplankton populations, as well as a closer collaboration between the government and the communities along the rivers draining to the lake to avoid polluting it. The urbanization process characterizing the nearby town of Nakuru also should be better studied as a means of avoiding direct pollution effects that could influence the lake's phytoplankton community structure. Furthermore, nutrient reduction strategies should be used to control the excessive phosphorus load to the lake, especially during the rainy seasons. In order to manage other saline-alkaline lakes, ecological approaches concerned with the phytoplankton community structure, and prevention of activities or measures through which this structure can be modified, should be used. With the use of such initiatives, water quality changes likely to cause adverse changes to the biotic assemblages can be discerned sufficiently early to allow corrective measures to be developed and implemented before irreparable ecological damages to the aquatic system occur.

\section{ACKNOWLEDGEMENTS}

The authors thank the Global Livestock Collaborative Research Support Program of the US-AID for their financial support through the Sustainable Management of Watershed (SUMAWA) Project, which facilitated this research. Sample collection was facilitated by Robert Ndetei of Kenya Wildlife Service (KWS). David Kulecho and Peter Ngatia of the Lake Nakuru Water Quality Laboratory assisted in analysis of water quality parameters. The monthly sample collection trips were organized by Mr Akula, to whom we are grateful to. We also acknowledge and appreciate the valuable comments 
provided by three anonymous reviewers that subsequently enriched the content of this paper.

\section{REFERENCES}

American Public Health Association (APHA) (1998) Standard Methods for the Examination of Water and Wastewater, 20th edn. American Public Health Association, Washington D.C.

Atici T. \& Olcay O. (2006) Seasonal variations of phytoplankton and value of chlorophyll $a$ in the Sariyar Dam Reservoir (Ankara, Turkey). Turk. J. Bot. 30, 349-57.

Bourrelly P. (1972) Les alques deau douce. Tome I: Les Algues Verts ed. Boubee, Paris.

Boyd C.E. (1990) Water quality for ponds in aquaculture. Birmingham Publishing Company, Birmingham, AL, USA.

Brower J. E., Zar J. H. \& von Ende C. N. (1990) Field and Laboratory Methods for General Ecology. William C. Brown Publishers, New York.

Burgis M. J. \& Morris P. (1987) Natural History of Lakes. Cambridge University Press, Cambridge, UK.

Death R. G. (2000) The effect of land use on the speciesarea relationships in benthic stream invertebrates. Verh. Int.Ver. Theor. Angew. Limnol. 27, 2519-22.

Egborge A. B. M. (1979) The seasonal distribution of phytoplankton of the lake Asejire - A new impoundment in Nigeria. Proceedings, International Conference on Kainji Lake and River Basins Development in Africa; 1117 December 1977, Ibadan, Nigeria.

Ettl H. (1983) Chlorophyta I. Phytomonadina. In: Subwasserflora Von Mitteleuropa (eds H. Ettl, J. Gerloff, H. Heynig \& D. Mollenhauer). Gustav Fischer-Verlag, Stuttgart-Jena, Germany.

Gurung T. G., Dhakal R. P. \& Bista J. D. (2006) Phytoplankton primary production, chlorophyll-a and nutrient concentration in water column of mountainous Lake Phewa, Nepal. Lake Reserv. Manage. 11, 141-8.

Howard-Williams C. \& Ganf G. C. (1981) Shallow lakes. In: The Ecology and Utilization of African Inland Waters (eds J. J. Symoens, M. Burgis \& J. J. Gaudet) pp. 103-13. United Nations Environment Programme, Nairobi, Kenya. Huber-Pestalozi G. (1938) Allgemeiner Teil. Blaualgen. Bacteria. Pilze. In: Das Phytoplankton Des Süsswassers, 1 Teil (ed. G. Huber-Pestalozi) pp. 1-6 + 1-342.

Hustedt F. (1942) Diatomeen. In: Das Phytoplankton Des Süsswassers, 2 Teil (2. Hälfte). (ed. G. Huber-Pestalozi) pp. I-X + 367-549. Schweizerbart'scheVerlagsburchhandlung, Stuttgart, Germany.

Jones C., Palmer R. M., Matkaluk S. \& Walters M. (2002) Watershed Health Monitoring: Emerging Technologies. CRC Press, Boca Raton, FL.
Kalff J. (2002) Limnology: Inland Water Ecosystems. Prentice Hall Inc. Upper Saddle River, NJ.

Kibichii S., Shivoga W. A., Muchiri M. \& Miller S. N. (2007) Macroinvertebrate assemblages along a land-use gradient in the upper River Njoro watershed of Lake Nakuru drainage basin, Kenya. Lake Reserv. Manage. 12, 107-17.

Komärek J. \& Fott B. (1983) Chlorophyceae (Grunalgen) Ordung: Chlorococcales. Das Phytoplankton des Süsswassers, 7. Teil (1. Hälfte). (ed. G. Hurber-Pestalozzi) pp. I-VII + 1044. Schweizerbart-sche-Verlagsbuchhandlung, Stuttgart, Germany.

Krammer K. \& Lange-Bertlot H. (1986-91) Bacillariophyceae. In: Subwasserflora Von Mitteleuropa (eds H. Ettl, J. Gerloff, H. Heynig \& D. Mollenhauer). Gustav Fischer-Verlag, Stuttgart-Jena, Germany.

Kruskal W. H. \& Wallis W. A. (1952) Use of ranks in one criterion analysis of variance. J. Am. Statis. Assoc. 47, 421-583.

Kuang Q., Yonghong B., Yicheng X. \& Zhenyu H. (2004) Phytoplankton community and algal potential in Taipinghu Reservoir, Anhui Province, China. Lake Reserv. Manage. 9, 119-24.

Lenzenweger R. (1996) Desmidiaceenflora Von Österrich teil 1. Stuttgart: J. Cramer.

Lorenzen C. J. (1969) Determination of chlorophyll and pheopigments. Spectrophotometric equations. Limno. Oceanogr. 12, 343-6.

Mellack J. M. \& Kilham P. (1974) Photosynthetic rates of phytoplankton in East African Soda Lakes. Oecologia 33, 220-6.

Michael E. G. \& Douglas E. S. (2004) Statistical Tools for Environmental Quality Measurement. 99, 900-01.

Milbrink G. (1975) On the limnology of two alkaline lakes (Nakuru and Naivasha) in the East Rift Valley System. Hydrobiologia 62, 1-17.

Mwatha W. E. (1983) Microbial biodiversity in soda lakes: A study of Lake Nakuru. (MSc Thesis). Kenyatta University, Nairobi, Kenya.

Ndetei R. \& Muhandiki V. S. (2005) Mortalities of lesser flamingos in Kenyan Rift Valley saline lakes and the implications for sustainable management of lakes. Lake Reserv. Manage. 10, 51-8.

Nkechinyere O.N. (2006) Seasonal variations in phytoplankton populations in Ogulebe Lake, a small natural west African lake. Lake Reserv. Manage. 11, 63-72.

Prescott G. W. (1954) How to Know Freshwater Algae. Brown Co., Dubuque, IA.

Reynolds C. S., Irish A. E. \& Eliot J. A. (2001) The ecological basis for stimulating phytoplankton responses to environmental change (PROTECH). Ecol. Model. 140, 271-91. 
Shivoga W. A., Muchiri M., Kibichi S. et al. (2007) Influences of land use/cover on water quality in the upper and middle reaches of River Njoro, Kenya. Lake Reserv. Manage. 12, 97-105.

Sileo L., Grootenhuise J. G., Tuite G. H. \& Hopcraft H. D. (1979) Microbacteriosis in the lesser flamingo of Lake Nakuru, Kenya. J. Wild. Dis. 15, 387-90.

StatSoft Inc. (2001) Statistica for Windows. StatSoft Inc., Tulsa, OK. http://www.statistica.com.

SUMAWA. (2004) Sustainable Management of Watersheds Programme: The River Njoro, Kenya. Environmental Sciences Department, Egerton University, Njoro, Kenya.

Talling J. F. \& Talling I. B. (1965) The chemical composition of African lake waters. Int. Rev. Hydrobiol. 50, 1-32.
Vareschi E. (1978) The ecology of Lake Nakuru (Kenya). 1. Cell density and feeding of the lesser flamingo. Oecologia 32, 11-35.

Vareschi E. (1982) The ecology of Lake Nakuru (Kenya). III. Abiotic factors and primary production. Oecologia $\mathbf{5 5}, 81-101$.

Vareschi E. \& Jacobs J. (1985) The ecology of Lake Nakuru (Kenya). VI. Synopsis of production and energy flow. Oecologia 65, 412-24.

Vollenweider R. A. (1969) A Manual on Methods for Measuring Primary Production in Aquatic Environments. IBP handbook no. 12. Blackwell, Oxford and Edinburgh, UK. Wetzel R. G. (1983) Limnology. CBS College Publishing, New York. 